\title{
Modeling of Hydrosalinity Balance within Kalaat El Andalous Irrigated District (Tunisia) using CIRFLE Model
}

\author{
Ahmed Saidi ${ }^{1}$, Hedi Daghari ${ }^{2}$ \\ ${ }^{1}$ Carthage University, National Agronomic Institute of Tunis, 43 Charles Nicolle Street, Mahrajene City, 1082 Tunis, Tunisia
}

\begin{abstract}
Throughout (2005-2010) period, the most important water balance value $\left(+3.64\right.$ million $\left.\mathrm{m}^{3}\right)$ was recorded during

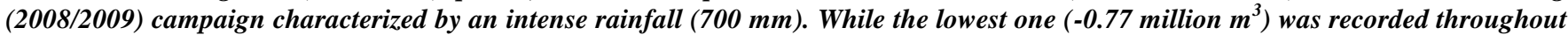
(2007/2008) campaign though it rainfall was only $333.5 \mathrm{~mm}$. Analysis of monthly water balance indicates generally farmers tendency to over-irrigation. Annual salts balance recorded during (1997-2011) period indicates a general tendency of the study area to desalination (average annual salts balance is about -37928.7 tons). Modeling of hydrosaline balance using CIRFLE model indicates that drainage water volume showed a linear variation with irrigation water volume and rainfall amount variations with dominance of rainfall effects by comparison to irrigation water volume ones. In fact, for the same variation index ( $+20 \%)$ of irrigation water volume and rainfall amount it was found that drainage water volume has increased by $10 \%$ and $25 \%$ respectively. However, CIRFLE simulations have shown that drainage water salinity variation is inversely proportional to irrigation water volume and rainfall amount variations. Thus, any increase of irrigation water volume and rainfall amount causes a decrease of drainage water salinity and vice versa with dominance of rainfall amount effects. On the other hand, it is noted that drainage water salinity is linear with that of irrigation water salinity. Furthermore, simulations have shown that evacuated salts amounts by drainage is proportional to irrigation water salinity, irrigation water volume and rainfall amount variations. Thus, it was found that rainfall effects dominate those of irrigation water volume whose dominate the effects of irrigation water salinity. Therefore, for the same variation index (+20\%), increases of evacuated salts amounts by drainage of $20 \%, 16 \%$ and $8 \%$ were recorded respectively with rainfall amount, irrigation water volume and irrigation water salinity increases.
\end{abstract}

Keywords: Water balance, Salts balance, Irrigation, CIRFLE, Soil salinity, Drainage, Kalaat El Andalous.

\section{Introduction}

Soil salinization is one of the major factors involved in agricultural productivity worldwide decline. Indeed, soil salinization already reduced or threatens, at short term, a significant part of the worldwide cultivable area. In fact, $6.5 \%$ of the world's land $\left(9\right.$ million $\left.\mathrm{km}^{2}\right)$ are already affected by salinization with varying degrees and unevenly spread over continents ([19]; [13]). This percentage increased to $39 \%$ in drylands and within every continent [5] since there is not enough rain to leach the salts beyond the rooting zone [10]. Salinization of irrigated land has become a global problem, especially in areas that are poorly drained and using large amounts of irrigation water. Reference [7] reported that nearly 20 to 30 million hectares worldwide are severely affected by salinity and about 60 to 80 million hectares are affected by other forms of degradation. Reference [21] provided an estimation of land affected by salinization (for irrigation) for the first four irrigators in the world such as India (11\%), Pakistan (21\%), the US (23\%) and Mexico $(10 \%)$. In Tunisia, prevailing problems of salinity are due to the presence of saline surface water table especially in the Majerda Valley, the Kairouan and oases. Thus, soils affected by salt cover about 1.5 million hectares which represent about $10 \%$ of Tunisian territory surface and $25 \%$ of the total area of arable land. These soils exist in the whole country but especially in the center and south where arid climate causes their extension [8]. For irrigated areas success and safeguarding, monitoring of watertable characteristics (level and water salinity) and soil salinity constitute a tool to predict and reduce salinization risks within irrigated soils. In this

context, throughout last decades an evaluation of hydrosalin balance have been performed within several irrigated areas around the world in order to assess salt loads in irrigation return flows (Australia: [14]; India: [18]; Iran: [11]; México: [12]; Spain: [6]; Tunisia, Turkey: [4]; USA: [17]). Nevertheless, the majority of studies was performed considering short periods of time and did not allow identifying long-term impacts of agronomic changes and climatic variability on salt load trends. So, models can be very useful tools in agriculture water management either in irrigation scheduling and crop water requirement estimation either in yields and soil salinization prediction. Hydro salinity models include simple models and more complex ones.

In intricate models, the process simulates the flow of water on the basis of Richards's equation by treating the salinity as a variable reactive state with basement chemistry models. In simple models, the space component of the root zone is typically assumed homogeneous, but the water movements are treated as distributed flows (deep percolation and root water extraction). Thus, modeling of hydrosaline balance over long periods and under different management scenarios is essential to prevent any negative impacts causing irrigated land degradation. In this study we were interested to the irrigated district of Kalaat El Andalous for which modeling of hydrosaline balance was carried out using CIRFLE model aiming to control both internal and external negative effects which could be generated by irrigation in arid and semi-arid lands.

\section{Volume 4 Issue 11, November 2015}




\section{International Journal of Science and Research (IJSR)}

ISSN (Online): 2319-7064

Index Copernicus Value (2013): 6.14 | Impact Factor (2014): 5.611

\section{Materials and methods}

\subsection{Description of the study area}

The study area of Kalaat El Andalous belongs to the Mejerda watershed and it took part on marshy and brackish areas characterizing the entrance of Mejerda wadi to the sea (latitude: $36^{\circ} 37^{\prime}$ and $37^{\circ} 2^{\prime} \mathrm{N}$; longitude: $10^{\circ} 5^{\prime}$ and $10^{\circ} 10^{\prime}$ E). This zone is located at $35 \mathrm{~km}$ north of Tunis in the NorthEast of Tunisia and almost reached the sea at Tunis Gulf and. Kalaat El Andalous irrigated area management was finished in 1987 and its exploitation began timidly in April 1992 on a flood area covering about 3000 ha. The irrigated area of Kalaat El Andalous is supplied with irrigation water from Sidi Salem dam's dumping in the Mejerda wadi which constitute the main water resource in the study area with a salinity ranging between $2.5 \mathrm{~g} / 1$ and $3.1 \mathrm{~g} / 1$ in winter and between $2.3 \mathrm{~g} / 1$ and $2.4 \mathrm{~g} / \mathrm{l}$ in summer. All the irrigated area is equipped with a pressurized irrigation network and the main irrigation techniques used are drip and sprinkler irrigation. Exploitation of this irrigated district has required the installation of a subsurface drainage network containing buried pipes drains, secondary collectors and open ditches. Soil survey within the irrigated area of Kalaat El Andalous indicates the existence of deep soils characterized by a fine texture ranging from silty-clay to clayey-silt [9]. The main practiced crops are cereals, fodder crops and vegetables. Fruit trees occupy a negligible surface area due to shallow watertable.

\subsection{Data acquisition and Kalaat El Andalous hydrosalinity balance}

\subsubsection{Climate and Crop Water Requirements}

To calculate reference evapotranspiration, we can use Cropwat software using the following climatic data: maximum temperature, minimum temperature, relative humidity and wind speed of the same weather station. However, measurement of evapotranspiration is complex and in order to facilitate the task and to homogenate models, researchers have estimated crop water requirement by correcting potential evapotranspiration (ET0) with a coefficient $\mathrm{Kc}$ (crop coefficient) using the following formula:

$$
\operatorname{ETR}(\text { crop })=K c \times E T_{0}
$$

ETR (crop): Real evapotranspiration (mm/month), ET0: Potential evapotranspiration ( $\mathrm{mm} / \mathrm{month})$ Kc: Crop coefficient which is function of crop and cropping stage [1]. For the whole study area, crop water requirements (ETRTotal) is calculated as following:

$$
E T R_{\text {Total }}=\frac{\sum E T R_{i} * S_{i}}{S}
$$

ETRi: Monthly real evapotranspiration of crop $i$ en (mm/month); Si: Area occupied by the crop i en (ha); S: Total area of the irrigated district (ha).

\subsubsection{Kalaat El Andalous hydrasalinity balance}

To evaluate hydro-saline balance within Kalaat El Andalous irrigated area, we proceed by collecting available data mainly rainfall, volumes and salinities of irrigation and drainage waters and cropping land use surface history during monitoring period. The rest of necessary data has been required using experiments and field measurements such as physical soil characterization, soil profile salinity monitoring and watertable depth and salinity monitoring. The irrigated area of Kalaat El Andalous is characterized with a very low slope, heavy soils and developed cropping cover generating often limited runoff. Therefore, runoff and lateral leakage have been neglected and capillary rise is included in soil water storage variation. Thus, equation used to calculate water balance in this study case is as following:

$$
\Delta W=(P+I)-(E T R+D+\Delta S)
$$

$\Delta \mathrm{W}$ : Water balance; P: Total rainfall during study period; I: Irrigation water volume; ETR: Real evapotranspiration (water requirement); $\mathrm{D}$ : Drainage water volume; $\Delta \mathrm{S}$ : Soil water storage variation.

Salts balance was calculated using equation based on the difference between salts amounts brought by irrigation water and those evacuated by drainage water. Indeed, other balance terms are negligible and simplified equation used for calculating salts balance is as following:

$$
\Delta \text { Salts }=V_{I} \times C E_{I}-V_{D} \times C E_{D}
$$

$\Delta$ Salts : Salts balance ( $\mathrm{Kg}$ ou ton); VI : Irrigation water volume $\left(\mathrm{m}^{3}\right)$; VD: Drainage water volume $\left(\mathrm{m}^{3}\right) ; \mathrm{CE}_{\mathrm{I}}$ : Irrigation water salinity $\left(\mathrm{Kg} / \mathrm{m}^{3}\right) ; \mathrm{CE}_{\mathrm{D}}$ : Drainage water salinity $\left(\mathrm{Kg} / \mathrm{m}^{3}\right)$.

\subsection{CIRFLE Model Description}

The conceptual irrigation return flow hydrosalinity model was developed by Tanji [20], revised by Aragues et al. ([2], [3]) with the name CIRF, and updated by Quilez [15] with the name CIRFLE (conceptual irrigation return flow hydrosalinity model with consideration of for leaching efficiency of salts). CIRFLE is a computer model estimating the volume of water and the salt concentration and loads in irrigation return flows. This model focuses on the crop's root zone and considers only the main flow-paths of water and salts in the system and assumes that masses of water and salt are conservative and that steady state conditions can model log-term transient conditions approximately. CIRFLE is based in a mass balance approach for water and salts taking into account only most important inputs and outputs from the system. Thus, inputs to the system are irrigation, precipitation and inflows from rim areas and outputs are evapotranspiration, irrigation and precipitation run off, subsurface drainage and deep percolation. Changes in soil storage are considered as the difference between initial and final states, with special attention to the leaching efficiency of salts and the calcite and gypsum dissolution-precipitation processes. CIRFLE does not model individual ions and thus cation exchange reactions or adsorption is not considered. The model has been designed in order to be applied to large systems and for long periods, such as an irrigation season, a hydrologic year, or a series of consecutive years. The model should not be applied for short periods as, in general, steady state conditions do not hold. CIRFLE consists of a hydrologic submodel coupled to a salinity submodel. In the hydrologic submodel the volume of water $\mathrm{Q}$ is considered. In the salinity submodel, the salt concentration (C) expressed as total dissolved solids (TDS), and the load or mass of salts

\section{Volume 4 Issue 11, November 2015}




\section{International Journal of Science and Research (IJSR) \\ ISSN (Online): 2319-7064}

Index Copernicus Value (2013): 6.14 | Impact Factor (2014): 5.611

(M) are considered. Salt load is obtained as the product of water volume, salt concentration and an adequate unit conversion factor (SMCF) that depends on the units of input data. Figure 1 gives a schematic representation of hydrologic submodel and the main inputs and outputs to an irrigation system. Considering the continuity equation, hydrologic submodel can be described as:

$$
\frac{d Q_{s}}{d t}=\sum_{j=1} Q_{i}-\sum_{k=l} Q_{o}
$$

Where: $\mathrm{Q}$ denotes volume of water and $\mathrm{t}$ denotes the time (hydrologic year). i, o, and $\mathrm{s}$ indices denote respectively inputs, outputs and water stored in the root zone.

Hydrologic inputs are described as following: $\sum_{j=1} Q_{i}=Q_{d i w}+Q_{p}+Q_{\text {rim }}+Q_{i s w}$

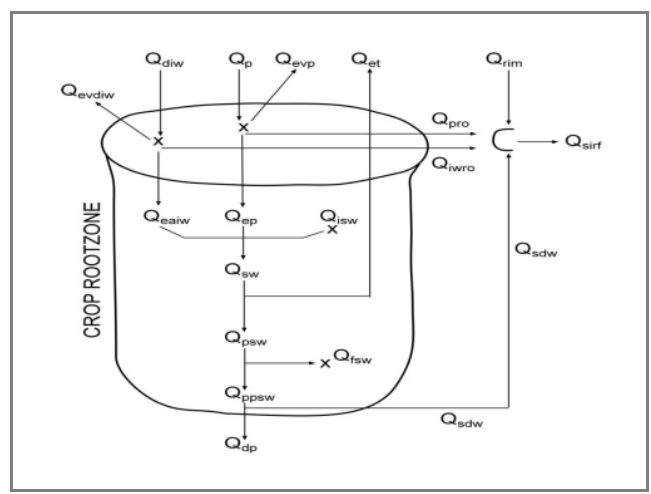

Figure 1: Hydrologic submodel diagram within the root zone

Where: diw, p, rim et isw indices denote respectively diverted irrigation water, precipitation, rim inflows from lateral systems and initial stored soil water. Hydrologic outputs are described as following:

$$
\sum_{k=1} Q_{o}=Q_{e t}+Q_{e t p}+Q_{d p}+Q_{f s w}+Q_{p r o}+Q_{i w r o}+Q_{s d w}+Q_{r i m}
$$

Where: et, etp, dp, fsw, pro, iwro et sdw indices denote respectively evapotranspiration, precipitation evaporation, deep percolation, final stored soil water, precipitation runoff, irrigation runoff and subsurface drainage.

Figure 2 shows the inputs, outputs and flow pathways considered in the salinity submodel. $\mathrm{C}$ denotes TDS (Total dissolved salts) or salts concentration ( $\mathrm{mg} / \mathrm{l})$, and $\mathrm{M}$ denotes the quantity of salts (tons). Considering the continuity principle, the salinity submodel can be described as following:

$$
\frac{d M_{s}}{d t}=\sum_{l=1} M_{i}-\sum_{m=l} M_{o}
$$

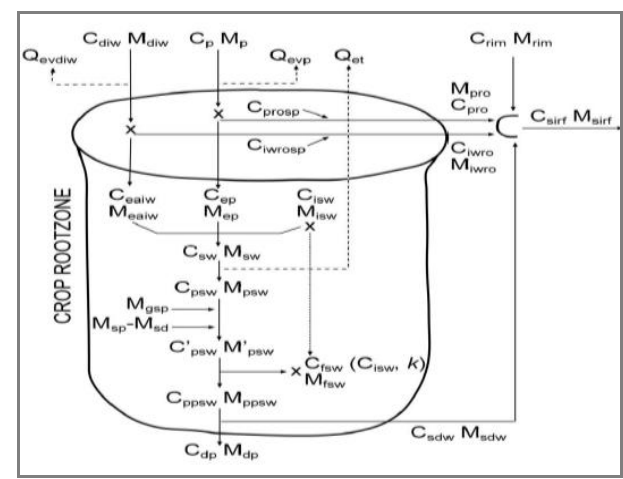

Figure 2: Salinity submodel diagram within the root zone
Where: $\frac{d \boldsymbol{M}_{s}}{d \boldsymbol{t}}$ denotes the variation rate of salts amount stored within the root zone.

The inputs to the system are described as following:

$$
\sum_{l=1} M_{i}=M_{d i w}+M_{p}+M_{r i m}+M_{i s w}+M_{s p}+M_{g s p}
$$

gsp index refers to gypsum dissolution and sp index denotes the mineral dissolution in the soil solution as source of salts and others indices where already defined when describing the hydrologic submodel.

The outputs to the system are described as following: $\sum_{m=1} M_{O}=M_{d p}+M_{s d w}+M_{p r o}+M_{i w r o}+M_{r i m}+M_{s d}+M_{f s w}$

Where: sd index refers to the quantity of salts deposition, or mineral dissolution-mineral precipitation occurring in the soil solution.

It is assumed that water traversing the surface ground tends to dissolve salts and that's why we have added Ciwrosp and Cprosp to Cdiw and $\mathrm{Cp}$, respectively, when calculating Miwro and Mpro. Salt load in surface irrigation return flows (Msirf) is the sum of the salt mass in subsurface drainage (Msdw), runoff components (Mpro and Miwro), and lateral contributions (Mrim) and the salt concentration of surface irrigation return flow (Csirf) is the volume-weighted average of the concentrations in the three components. CIRFLE model estimates also certains indicators of irrigation efficiency such as: Ditrict irrigation efficiency, drainage fraction and water use efficiency. It was shown that CIRFLE model is useful for the evaluation of salinity control practices such as reduction of applied irrigation water volume, irrigated district modernization (replacement of irrigation systems) and reuse of drainage water for irrigation [2]. Thus, modeling of certain management strategies helps to choose those which are the most appropriate for irrigation water return flows salinity control.

\section{Results and discussion}

\subsection{Climate and crop water requirements}

During (1997-2011) period, average annual rainfall is about $512.5 \mathrm{~mm}$ and ranged from $275.0 \mathrm{~mm}$ (2001) to $857.5 \mathrm{~mm}$ (2003). Seasonal rainfall distribution indicates that rainfall amounts are concentrated in autumn and winter seasons with $394.5 \mathrm{~mm}(77 \%)$. However, during summer season, average rainfall amount did not exceed $13 \mathrm{~mm}(2 \%)$ hence the recourse to irrigation to satisfy crop water requirements. Average monthly rainfall ranged between $1.3 \mathrm{~mm}$ and 91.0 $\mathrm{mm}$ respectively in August and December.

Standard evapotranspiration was determined using CROPWAT software (Allen et al., 1998) involving several climate data. Thus, we note that standard evapotranspiration (ET0) remains relatively low during winter season (December: $68.8 \mathrm{~mm} / \mathrm{month}$ ) and becomes increasingly important during summer months (August: 165.2 $\mathrm{mm} /$ month). To calculate the total evapotranspiration amount within the whole irrigated area, evapotranspiration value of each crop should be multiplied by a weighting factor

\section{Volume 4 Issue 11, November 2015}




\section{International Journal of Science and Research (IJSR) \\ ISSN (Online): 2319-7064}

Index Copernicus Value (2013): 6.14 | Impact Factor (2014): 5.611

corresponding to the ratio of the area occupied by each crop divided by the total irrigated study area. Throughout (20052010) period, annual evapotranspiration ranged from 16.4 to 18.4 million $\mathrm{m}^{3}$ (average annual value: 17.1 million $\mathrm{m}^{3}$ ). During full irrigation period (March-September), evapotranspiration amount ranged from 9.5 to 11.6 million $\mathrm{m}^{3}$ and during the remaining period (October-February), evapotranspiration amount ranged from 6.8 to 7.2 million $\mathrm{m}^{3}$.

\subsection{Irrigation and Drainage Management}

During (1997-2011) period, irrigation water volume fluctuated between 3.5 million $\mathrm{m}^{3}$ (1997) and 12.1 million $\mathrm{m}^{3}$ (2002) and average of annual irrigation water volume is about 8.8 million $\mathrm{m}^{3}$. Indeed, at the beginning of Kalaat El Andalous irrigated area exploitation irrigated areas were very limited and since 2000 these latter have evolved considerably thereby water volumes assigned to irrigation have increase. Maximum irrigation volume was recorded in 2002 due to low rainfall amounts $(348 \mathrm{~mm})$. Through full irrigation season (March to September), average cumulative amount totalize 7.6 million $\mathrm{m}^{3}$ (87\% of total irrigation water volume). However, during (October-February) period average cumulative water volume is about 1.2 million $\mathrm{m}^{3}$, which represent $13 \%$ of total irrigation water volume. During (1997-2011) period, average irrigation water salinity ranged between 1.7 to $2.7 \mathrm{~g} / 1$ (average salinity: $2.2 \mathrm{~g} / \mathrm{l}$ ). Generally, irrigation water salinity reaches higher values during (November to February) period of each year. Such increase is due to drainage water discharges into Mejerda wadi derived notably from Chafrou wadi. Irrigation water is therefore considered of poor quality whose utilization must be coupled to an adequate drainage and adequate leaching in order to avoid soil salinization risk. Monitoring of drainage water volume revealed that evacuated water amounts out of study area are mainly related to rainfall events and secondly to delivered irrigation water volumes. During (1997-2011) period, annual average drainage water volume is approximately 6.6 million $\mathrm{m}^{3}$. Thus, minimum volume $(3.6$ million $\mathrm{m}^{3}$ ) was drained in 1997 while maximum one (15.6 million $\mathrm{m}^{3}$ ) was recorded in 2003 (wet year: $857.5 \mathrm{~mm}$ ). However, throughout full irrigation period (MarchSeptember) monthly drained water volume fluctuated between 0.3 and 0.7 million $\mathrm{m}^{3}$ derived mainly from irrigation water inflows. Through the monitoring period (1997-2011), average drainage water salinity is about $9.4 \mathrm{~g} / \mathrm{l}$ however, at the beginning of the irrigated district exploitation salinity was $15 \mathrm{~g} / \mathrm{l}$ approximately indicating high soil salinity. After ten years, drainage water salinity had shown a net decrease $(6$ to $7 \mathrm{~g} / \mathrm{l})$ indicating a general tendency to soil desalination.

\subsection{Hydrosaline Balance}

During (2005-2010) period, annual water balance ranged from -0.77 to +3.64 million $\mathrm{m}^{3}$. The most important water balance value was recorded during (2008/2009) campaign characterized by an intense rainfall $(700 \mathrm{~mm})$. While the lowest one $\left(-0.77\right.$ million $\left.\mathrm{m}^{3}\right)$ was recorded throughout (2007/2008) campaign in which rainfall was only $333.5 \mathrm{~mm}$. Analysis of monthly water balance has leaded to identify two distinct phases: a first phase spanning (September-May) period during which water balance showed highly variable tendency and a second phase spanning (June-August) period through which water balance is always positive indicating a general tendency of farmers to over-irrigation. Analysis of annual salts balance during (1997-2011) period indicates a general tendency of the study area to desalination. In addition, all salts balances calculated for any campaign show that drained salts amounts exceed those brought to the system by irrigation and precipitation and average annual salts balance is about -37928.7 tons. At monthly scale, we note the succession of two different phases. Results referring to (1997-2001) and (2003-2004) periods indicate that study area is marked only by soil desalinization and extreme recorded values fluctuated from -8887.4 to -182.5 tons and from -12396.2 - to -1819.0 tons respectively. However, in 2002 and during (2005-2011) period, we note a succession of two phases: one phase of salinization and another phase of desalination. For example, in 2002, accumulated salts amount in soil was 1982.0 tons while evacuated salts amount was 12202.0 tons. Thus, we note that over years there is a general tendency to study area desalinization. But in reality, monthly analysis of salt balance revealed soil salts accumulations mainly during (May-November) period coinciding largely with irrigation season when crops are already in place. Therefore, regular monitoring of soil salinization at field scale is very necessary to struggle negative impacts of brakish waters use.

\subsection{Modeling of hydrosalinity balance within Kalaat El Andalous irrigated area using CIRFLE model}

In order to get an idea about the study area tendency to salinization a modeling test was performed using CIRFLE model.

\subsubsection{Inputs/Outputs of CIRFLE model}

CIRFLE model involves 25 inputs that can be measured, estimated or extracted from literature. These inputs are described as following:

IA: Irrigated area (ha). In this case, average study area is about 750 ha.

Qdiw: Measured irrigation water volume $\left(10^{6} \mathrm{~m}^{3}\right)$.

Eiae: Fraction of irrigation water which infiltrates into the soil. In this case, Eiae $>90 \%$ (drip irrigation and sprikler irrigation)

Iwec: Percentage of irrigation water lost by evaporation estimated at $1 \%$. (iwec $<1$-Eiae)

Qp: Rainfall water volume $\left(10^{6} \mathrm{~m}^{3}\right)$

Prc: Runoff coefficient of rainfall water. Within Mejreda watershed, this coefficient is about $7 \%$.

Pec: Pourcentage of evaporated rainfall water (estimated at 4 $\%$.

Cdiw: Salts concentration of irrigation water (mg/l)

Ciwrp: Salts concentration of runoff from irrigation water (mg/l), (estimated at $2500 \mathrm{mg} / \mathrm{l})$.

Qisw: Initial water content within irrigated soil measured at the beginning of hydrologic year.

Qfsw: Final water content within irrigated soil measured at the end of hydrologic year.

Dr: Average root zone depth (m).

\section{Volume 4 Issue 11, November 2015}




\section{International Journal of Science and Research (IJSR) \\ ISSN (Online): 2319-7064 \\ Index Copernicus Value (2013): 6.14 | Impact Factor (2014): 5.611}

ETc: Calculated crop evapotranspiration $\left(10^{6} \mathrm{~m}^{3}\right)$.

Dpc: Coefficient of deep percolation (estimated at 0 because the whole percolated water will be evacuated by drainage network located at $-1.6 \mathrm{~m}$ depth.

Qrim: Exterior water amounts from other irrigated districts (neglected in this case) $\left(\mathrm{m}^{3}\right)$.

Crim: Salts concentration of exterior water amounts Qrim $(\mathrm{mg} / \mathrm{l})$.

Sp: Pourcentage of saturation

Db: Bulk density $\left(\mathrm{g} / \mathrm{cm}^{3}\right)$

Gypsum: Pourcentage of gypsum in the soil. In this case, this term is neglected [16].

$\mathrm{K}$ : Salts leaching efficiency. According to literature, this coefficient ranges between 0.3 and 0.35 for clay-loam soils.

Cp: Salts concentration of rainfall water $(30 \mathrm{mg} / \mathrm{l})$.

Cprosp: Salts concentration of runoff from rainfall water (1500 mg/l).

EC: Electrical conductivity of soil paste saturated extract $(\mathrm{dS} / \mathrm{m})$.

$\mathrm{a}$ et $\mathrm{b}$ : Constant values determined from iterations.

The main outputs of CIRFLE model are:

$Q$ sirf: Drainage water volume $\left(10^{6} \mathrm{~m}^{3}\right)$

C sirf: Salts concentration of drainage water $(\mathrm{g} / \mathrm{l})$

M sirf: Evacuated salts amounts by drainage (tons)

\subsubsection{Model Calibration}

The main parameters modified for model calibration are irrigation water application efficiency (Eiae), percentage of evaporated irrigation water (iwec), runoff percentage of rain water (prc), leaching efficiency $(\mathrm{K})$ and $\mathrm{a}$ and $\mathrm{b}$ constants values. These latter were estimated and measured parameters were not changed. Iterations have been made until provided results provided by the model are close to measured values. A difference index (Diff \%) was used in order to compare calculated values (model) with those measured.

$$
\text { Diff } \%=\left(1-\frac{\text { Calculated } . \text { value }}{\text { Measured.value }}\right) * 100
$$

This index should be as low as possible and did not exceed $20 \%$ (error generated while estimating inputs/outputs of water balance).

Table 1: CIRFLE Model calibration results

\begin{tabular}{|c|c|c|c|}
\hline Parameters & $\begin{array}{c}\text { Measured } \\
\text { value }\end{array}$ & $\begin{array}{c}\text { Calculated } \\
\text { value }\end{array}$ & $\begin{array}{c}\text { Difference } \\
\text { index (\%) }\end{array}$ \\
\hline $\begin{array}{c}\text { Drainage water volume } \\
\text { Qsirf }\left(10^{6} \mathrm{~m}^{3}\right)\end{array}$ & 7.4 & 7.6 & -2.1 \\
\hline $\begin{array}{c}\text { Salts concentration of } \\
\text { drainage water Csirf(g/l) }\end{array}$ & 6.9 & 5.6 & 19.8 \\
\hline $\begin{array}{c}\text { Evacuated salts amount by } \\
\text { drainage Msirf (tons) }\end{array}$ & 47981.4 & 42178.3 & 12.1 \\
\hline
\end{tabular}

\subsubsection{Model Validation}

After model calibration involving data of 2008/2009 season, we will apply CIRFLE model respectively for a dry season, an average season and a wet season in order to test and verify its reliability.
Table 2: Model response to different rainfall regims

\begin{tabular}{|c|c|c|c|c|}
\hline Year & Parameters & $\begin{array}{c}\text { Drainage } \\
\text { water } \\
\text { volume } \\
\text { Qsirf } \\
\left(10^{6} \mathrm{~m}^{3}\right) \\
\end{array}$ & \begin{tabular}{|c|} 
Salts \\
concentration \\
of drainage \\
water Csirf \\
$(\mathrm{g} / \mathrm{l})$
\end{tabular} & $\begin{array}{l}\text { Evacuated } \\
\text { salts amount } \\
\text { by drainage } \\
\text { Msirf (tons) }\end{array}$ \\
\hline \multirow{3}{*}{$\begin{array}{c}\text { Dry season } \\
(2007 / 2008) \\
(\mathrm{P}=334 \mathrm{~mm})\end{array}$} & $\begin{array}{c}\text { Measured } \\
\text { value }\end{array}$ & 5.4 & 5.9 & 31858.0 \\
\hline & $\begin{array}{c}\text { Calculated } \\
\text { value }\end{array}$ & 4.3 & 6.8 & 29745.9 \\
\hline & Diff $(\%)$ & $20.9 \%$ & $-15.5 \%$ & $6.6 \%$ \\
\hline \multirow{3}{*}{$\begin{array}{c}\text { Average } \\
\text { season } \\
(2005 / 2006) \\
(\mathrm{P}=520 \mathrm{~mm})\end{array}$} & $\begin{array}{l}\text { Measured } \\
\text { value }\end{array}$ & 7.9 & 6.3 & 46069.0 \\
\hline & $\begin{array}{c}\text { Calculated } \\
\text { value }\end{array}$ & 6.6 & 5.9 & 39189.4 \\
\hline & Diff (\%) & $16.5 \%$ & $6.4 \%$ & $14.9 \%$ \\
\hline \multirow{3}{*}{$\begin{array}{l}\text { Wet season } \\
(2009 / 2010) \\
(\mathrm{P}=700 \mathrm{~mm})\end{array}$} & $\begin{array}{l}\text { Measured } \\
\text { value }\end{array}$ & 7.4 & 6.9 & 47981.4 \\
\hline & $\begin{array}{c}\text { Calculated } \\
\text { value }\end{array}$ & 8.0 & 5.3 & 43105.3 \\
\hline & $\operatorname{Diff}(\%)$ & $-7.4 \%$ & $23.6 \%$ & $10.2 \%$ \\
\hline
\end{tabular}

Results presented in Table 2 indicate good correlation between measured and calculated values independently of rainfall regimes. However, slight discrepancies arise that can be attributed to measurement errors.

\subsubsection{Analysis Of Some Scenario}

Various scenarios were analyzed in order to check the tendency of hydro-saline balance within the study area according to an irrigation water supply variation, a rainfall variation and to an irrigation water salinity variation.

\section{- Analysis of an irrigation water volume variation}

Because farmers use exceccive water volumes with copparison to crops water requirements, it was deemed useful to test the effect of an irrigation water volume variation on hydro-saline balance tendency. A reduction of irrigation water amounts of $-10 \%,-20 \%,-30 \%,-40 \%$ and $-50 \%$ was applied. The sensitivity of the model was also analyzed regarding to an increase of irrigation water volumes $(10 \%$, $20 \%, 30 \%, 40 \%$ and $50 \%$ ). The effect of these variations on drainage water volume, drainage water salinity and evacuated salts amount by drainage is shown in Figure 3.

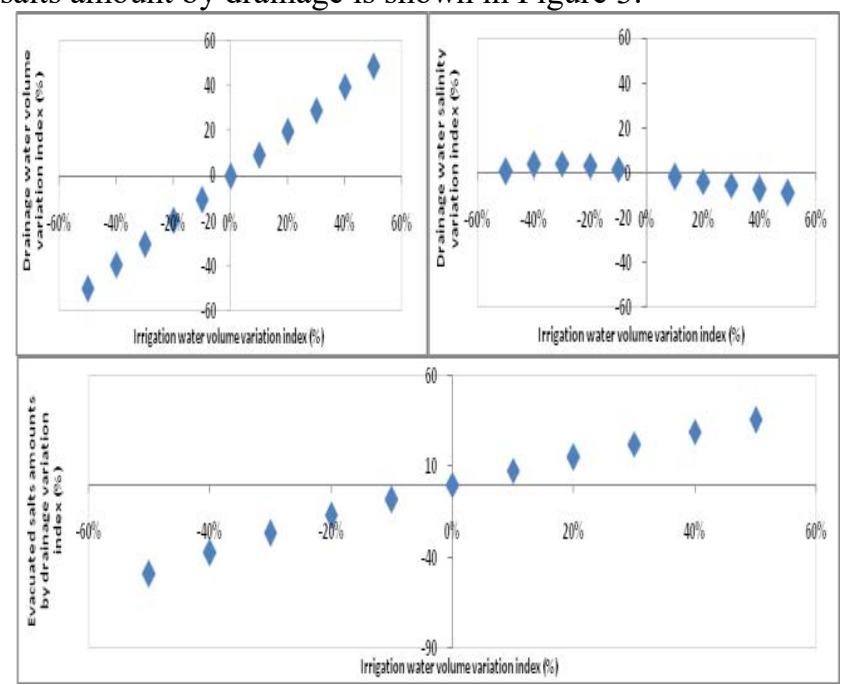

Figure 3: Effect of irrigation water volume variation on drainage water volume, drainage water salinity and evacuated salts by drainage 


\section{International Journal of Science and Research (IJSR) \\ ISSN (Online): 2319-7064}

Index Copernicus Value (2013): 6.14 | Impact Factor (2014): 5.611

Referring to Figure 3, it was found that drainage water volume and evacuated salts amounts by drainage showed a linear variation with irrigation water volume variation. However, drainage water salinity variation is inversely proportional to irrigation water volume variation. Thus, any increase of irrigation water volume causes a decrease of drainage water salinity and vice versa.

\section{- Analysis of rainfall amount variation}

The sensitivity of the model was also analyzed with respect to an increase $(10 \%, 20 \%, 30 \%, 40 \%$ and $50 \%)$ or a decrease $(-10 \%,-20 \%,-30 \%,-40 \%$ and $-50 \%)$ of rainfall amount (Figure 4).

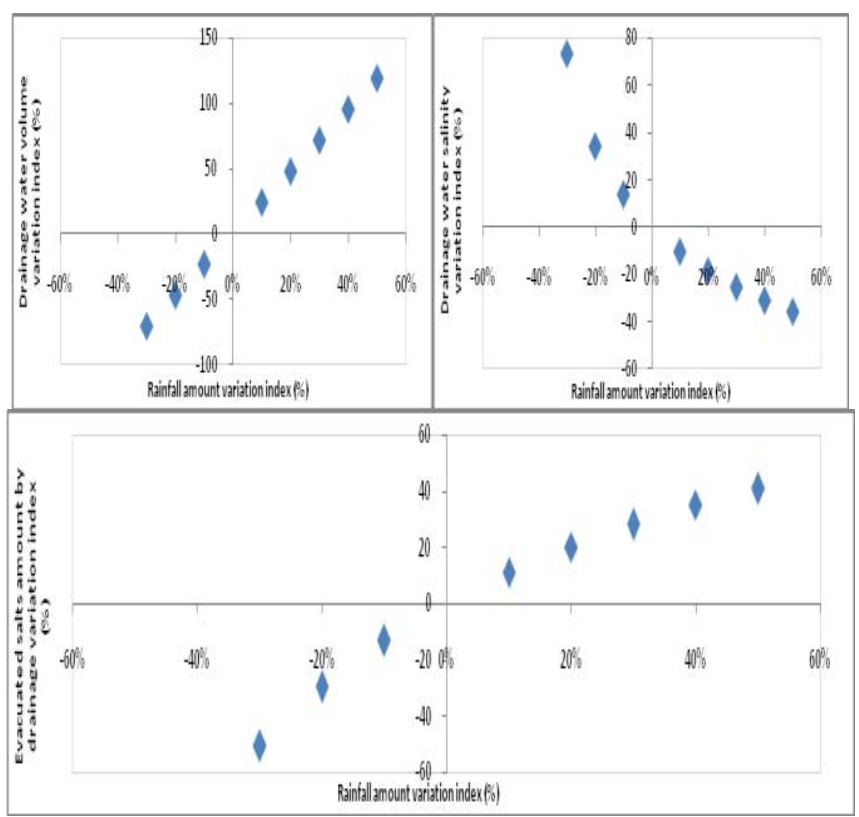

Figure 4: Effect of rainfall amount variation on drainage water volume, drainage water salinity and evacuated salts by drainage

Variations of rainfall amounts generated similar effects to those generated by varying the volume of irrigation water. Indeed, drainage water volume and evacuated salts amounts by drainage variations are linear with rainfall amount variation. However, drainage water salinity variation is inversely proportional to rainfall variation.

\section{- Analysis of irrigation water salinity variation}

The model was also analyzed with respect to an increase $(10 \%, 20 \%, 30 \%, 40 \%$ and $50 \%)$ or a decrease of irrigation water salinity $(-10 \%,-20 \%,-30 \%,-40 \%$ and $-50 \%)$ (Figure $5)$.

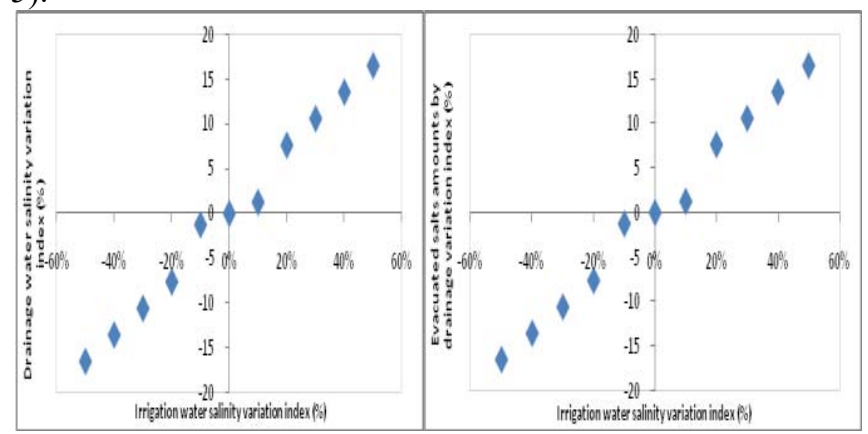

Figure 5: Effect of irrigation water salinity on drainage water salinity and evacuated salts by drainage
With reference to Figure 5, it is noted that drainage water salinity and evacuated salts amounts by drainage variation is linear with that of irrigation water salinity. Therefore, land salinization problems become more pronounced if using poor quality water. However, heavy rains could struggle against accumulated salts damage by draining them out of the system.

\section{Conclusion}

Given water resources scarcity and increased competition for water of good quality between different users, farmers are forced to irrigate with poor quality water and obliged to rationalize the water use by introduction of water saving irrigation techniques. In this context, $70 \%$ of Tunisian irrigated areas are equipped with water saving systems. Drip irrigation is an efficient technique, but when brackish waters are used a lot of precautions should be taken. Moreover, analysis of hydrosalinity balances revealed farmers' tendency to over-irrigation which constitute an important source of water losses involving excessive amounts of salts that contribute to soil salinization, especially when leaching doses and irrigation schedule are not taken into account. In this study, simulations with CIRFLE model have shown that evacuated salts amounts by drainage variation is proportional to irrigation water salinity, irrigation water volume and rainfall amount variations. Thus, farmers' tendency to overirrigation constitutes an important factor leading to soil salinization. So, irrigation scheduling remains very useful in order to save water resources and to struggle against soil salinization risks. Hence, modeling constitutes a simple tool that can be used in order to simulate others scenarios like irrigated surface extension, drainage network and groundwater table depth effects on soil salinization.

\section{References}

[1] Allen R.G., Pereira L.S., Raes D., Smith, M., 1998. Crop evapotranspiration (guidelines for computer crop water requirements). FAO Irrigation and Drainage Paper No. 56, Food and Agricultural Organization of the United Nations, Rome.

[2] Aragüés, R., Tanji, K.K., Quílez, D., Alberto, F., Faci, J., Machín, J. y Arrúe, J.L. (1985). Calibration and Verification of an Irrigation Return Flow Hydrosalinity Model, Irrigation Science. V-6, pp. 85-94.

[3] Aragüés, R., Tanji, K.K., Quilez, D., Faci, J. (1990). Conceptual irrigation project hydrosalinity model, Chapter 24. In: Agricultural salinity assessment and management. American Society of Civil Engineering. New York, USA, pp. 504-529.

[4] Aragüés, R., Urdanoz, V., Cetin, M., Kirda, C., Daghari, H., ltifi, W., Lahlou, M., Douaik, A. (2011). Soil salinity related to physical soil characteristics and irrigation management in four Mediterranean irrigation districts. Agricultural Water Management. 98, pp. 959-966. doi:10.1016/j. agwat.2011.01.004.

[5] Cheverry C. et Bourrie G., 1998. La salinisation des sols. Dans : Sol, interface fragile, Stengel P. et Gelin I. [Éditeurs], INRA Edition, 109-123. 


\section{International Journal of Science and Research (IJSR) \\ ISSN (Online): 2319-7064}

Index Copernicus Value (2013): 6.14 | Impact Factor (2014): 5.611

[6] Faci, J.M., Bensaci A., Slatni A., Playan E., 2000. A case study for irrigation modernization. I. Characterization of the district and analysis of water delivery records. Agric. Water Manage. 42, 313-334.

[7] FAO, 1990. Management of gypsiferous soils. Soils Bulletin 62, $81 \mathrm{p}$.

[8] Hachicha M., 2007. Les sols salés et leur mise en valeur en Tunisie. Science et changements planétaires/Sécheresse -Volume 18, numéro 1 : pages 45 50

[9] Ibrahimi. K., 2003. Indicateurs de la qualité des terres : Contribution à l'élaboration des indicateurs et mise au point d'un système fonctionnel de suivi de la salinité des terres irriguées de la vallée de Mejreda. Mémoire de Mastère de l'INAT.

[10] Miller R.W., and Donahue R.L., 1995. Soils in our environment, 7th Ed. Prentice Hall Inc., Englewood Cliffs, New Jersey. 649p.

[11] Noory, H., van der Zee, S.E.A.T.M., Liaghat, A.-M., Parsinejad, M., van Dam, J.C. (2011). Distributed agrohydrological modelling with SWAP to improve water and salt management of the Voshmgir irrigation and drainage network in Northern Iran. Agriculture Water Management, 98, pp. 1062-1070. doi:10.1016/j.agwat.2011.01.013.

[12] Palacios, O., Escamilla, M., Reyes, A. (1978). El balance de sales del distrito de Mexicali, B. C. National Resources. J. V-18, pp. 49-67.

[13] PNUE, 1992. Sauver notre planète. PNUE, Nairobi.

[14] Prendergast J.B., Rose C.W., and Hogarph W.L., 1994. Sustainability of conjunctive water use for salinity control in irrigation areas: theory and application to the Shepparton region, Australia. Irrigation Science 14, 177187.

[15] Quílez, D. (1998). The salinity in the surface waters of the Ebro Basin: Potential Impact Analysis of Monegros II Irrigation. $\mathrm{PhD}$ thesis. Department of Environment and Soil Science, Technical School Of Agricultural Engineering, University of Lleida, Lleida, Spain, p. 352.

[16] Saker S., 2008. Dynamique de l'azote minéral dans le sol-Cas du périmètre irrigué de Kalâat El Andalous. Mastère de recherche à la faculté des sciences de Tunis.

[17] Schoups G., Hopmans J.W., and Tanji K.K., 2005. Sustainability of irrigated agriculture in the San Joaquin Valley, California. PNAS 102, 15352-15356.

[18] Sharma, B.R. (1999). Regional salt- and water-balance modeling for sustainable irrigated agriculture. Agriculture Water Management. V-40, pp.129-134.

[19] Szabolcs I., 1987. The global problems of salt affected soils. Area Argon. Budapest, Hung. 36. (1-2). 159-172.

[20] Tanji. K.K., 1977. A steady state conceptual nitrogen model for estimating nitrogen emission from cropped lands. J. Environ. Qual-6, 155-159.

[21] Umali D.L., 1993. Irrigation-induced salinity. A growing problem for development and the environment. World Bank technical paper 215, p.78.

\section{Author Profile}

Dr. Ahmed SAIDI is a native of Tunisia. He has obtained his Engineer degree from the Higher Agronomic Institute of ChottMariem-Sousse and then his Master of Science and doctorate degrees from the National Agronomic Institute of Tunisia in the field of Rural Engineering, Water and Forests. Currently, he is working in the National Researches Institute of Rural Engineering, Water and Forests as an engineer specialized in hydraulic and irrigation. 